\title{
Thymic Tumor pT1 TNM Finding v8
}

National Cancer Institute

\section{Source}

National Cancer Institute. Thymic Tumor PT1 TNM Finding v8. NCI Thesaurus. Code

C136308.

Thymic tumor which is encapsulated or extends into the mediastinal fat; may involve the mediastinal pleura. (from AJCC 8th Ed.) 